\section{Anna Jaroszewska \\ Uniwersytet Warszawski https://orcid.org/0000-0003-2788-593X \\ a.jaroszewska@uw.edu.pl}

\section{Piotr Milewski}

Uniwersytet Warszawski https://orcid.org/0000-0003-0273-6989

p.milewski8@student.uw.edu.pl

Katarzyna Posiadała

Uniwersytet Warszawski https://orcid.org/0000-0002-8053-7574 katarzyna.posiadala@uw.edu.pl

\title{
Analiza korelacji pomiędzy nasileniem cech osobowości a strategiami uczenia się leksyki na przykładzie polskich uczqcych się języka niemieckiego na trzecim etapie edukacyjnym
}

\author{
Analysis of the correlation between personality traits and \\ Vocabulary Learning Strategies on the example of Polish learners \\ of German at the third stage of education
}

Developing learners' lexical subsystem is one of the most important tasks of foreign language didactics. The observable turn towards vocabulary ("Wortschatzwende") has contributed to an in-depth reflection on learners' lexical competence, including their strategic competence. The aim of this paper is to present results of a correlating research concerning the influence of personality variables (understood according to the Five-Factor Model) on the range and frequency of strategies used by Polish high-school students to learn German vocabulary. The research project described in this paper was conducted in April 2021. The Polish 
adaptation of the NEO Five-Factor Inventory was applied to examine the learners' personality traits. The Polish version of Schmitt's Vocabulary Learning Strategies Questionnaire (VLSQ) was used to investigate students' preferred strategies for learning German vocabulary. Based on the conclusions from the research, an attempt was made to formulate practical guidelines for foreign language teachers concerning the possibilities of developing learners' lexical competence. The report is complemented by a list of open research questions and problems in this field.

Keywords: vocabulary learning strategies, five-factor model of personality, NEO-FFI, Big Five, Vocabulary Learning Strategies Questionnaire, vocabulary, lexical competence

Słowa kluczowe: strategie uczenia się słownictwa obcojęzycznego, pięcioczynnikowy model osobowości, NEO-FFI, Wielka Piątka, kwestionariusz strategii uczenia się słownictwa, słownictwo, kompetencja leksykalna

\section{Wstęp}

Zarówno badacze, jak i praktycy (nauczyciele języków obcych) podkreślają znaczenie rozwijania podsystemu leksykalnego w procesie kształtowania kompetencji komunikacyjnej uczących się. W każdym działaniu językowym niezbędna jest bowiem znajomość słownictwa i jego opanowanie w zakresie recepcji i produkcji językowej (Tschirner, 2010: 242; Targońska, Stork, 2013: 71 nn.).

W podejściu kognitywnym, komunikacyjnym i interkulturowym, w których zaczęto uwzględniać wyniki badań z obszaru pragmalingwistyki, ranga słownictwa w nauczaniu/ uczeniu się języka obcego niepomiernie wzrosła. Słownictwo umożliwia bowiem uczącym się poznanie przestrzeni socjosemantycznej, świata kulturowego użytkowników języka docelowego i aktywne w nim uczestnictwo. Deficyty w zakresie znajomości słownictwa prowadzą najczęściej do zaburzeń komunikacji, blokują lub znacznie zakłócają przekaz językowy (Komorowska, 2005: 151).

Analiza badań empirycznych dotycząca znajomości słownictwa uczących się języków obcych w Polsce prowadzi do wniosku, iż poziom opanowania podsystemu leksykalnego jest niezadowalający i odbiega od rekomendacji dotyczących jego recepcji i produkcji zawartych w ESOKJ dla poszczególnych poziomów biegłości językowej oraz przyjętych dla konkretnych etapów edukacyjnych (Targońska, 2011, 2016). Odnosi się to również do kandydatów na studia filologiczne i lingwistyczne. W tym kontekście w nauce języka obcego nabiera znaczenia trening strategiczny, ukierunkowany na świadomy dobór i zastosowanie przez uczących się strategii uczenia się słownictwa obcojęzycznego. 
Analiza korelacji pomiędzy nasileniem cech osobow ości a strategiami uczenia się...

Celem artykułu jest zaprezentowanie wyników badań nad korelacją zmiennych osobowościowych, rozumianych zgodnie z paradygmatem cechowym (model ,Wielkiej Piątki") i strategiami uczenia się słownictwa na przykładzie polskich uczących się języka niemieckiego na trzecim etapie edukacyjnym.

\section{Strategie uczenia się słownictwa obcojęzycznego i taksonomia N. Schmitta (1997)}

Strategie uczenia się języków obcych stanowią, przynajmniej od przełomu lat 80. i 90. XX wieku, istotny temat badań naukowych i rozważań teoretycznych z zakresu dydaktyki obcojęzycznej (Rubin, 1981; O’Malley, Chamot, 1990; Oxford, 1990). Punkt wyjścia do badań stano wiła obserwacja specyficznych cech i zachowań uczniów uzdolnionych, którzy poprzez określone działania byli w stanie usprawniać proces uczenia się języka (Rubin, 1975; Stern, 1975; Naiman i in., 1978). Dalsze badania wykazały, że właściwie przeprowadzony trening strategiczny pozwala na jeszcze bardziej efektywne zastosowanie strategii, co w konsekwencji może przekładać się na osiągnięcie lepszych wyników w nauce języka obcego (Chamot, Harris, 2019) ${ }^{1}$. W ciągu ponad czterdziestoletniej historii badań nad strategiami uczenia się języków obcych wielu badaczy proponowało różne definicje strategii uczenia się oraz wiele ich taksonomii (Grenfell, M acaro, 2007). Dziś więc już wiadomo, że strategie są nie tylko mentalnymi procesami, lecz mogą mieć również charakter fizyczny, a zatem można je obserwować. Uczący się często wykorzystują je w sposób celowy, elastyczny i twórczy; łącząc je ze sobą w różny sposób, np. w ciągi działań, w określonych celach, aby sprostać swoim potrzebom edukacyjnym. Strategii można się nauczyć. To uczący się, w zależności od danej sytuacji, decyduje, jaką strategię powinien wybrać. Jako że przydatność strategii zależy od wielu czynników osobistych i kontekstualnych (Oxford 2017: 48), podejmując problematykę związaną ze stosowaniem strategii uczenia się języków obcych, warto skoncentrować się na konkretnym podsystemie językowym określonej grupy uczących się (Pawlak, Oxford, 2018).

W centrum zainteresowania opisywanego projektu badaw czego znajdowało się stosowanie strategii uczenia się słownictwa języka niemieckiego w grupie uczących się abiturientów. Strategie te rozumiane są jako złożoność i dynamiczność świadomych myśli oraz zachowań, które uczący się wybiera w sposób zamierzony i stosuje w określonych kontekstach w celu samoregulacyjnego, autonomicznego rozwoju słownictwa obcojęzycznego służącego efektywnemu wypełnianiu zadań i zmierzającego do zwiększenia biegłości w języku docelowym (Oxford, 2017: 244). Aby dane działanie uczącego się można było nazwać strategią, powinno ono (Nation, 2001: 217):

${ }^{1}$ Dotyczy to również uczniów o mniejszych uzdolnieniach językowych. 
- uwzględniać możliwość wyboru,

- być zbiorem czynności podejmowanych przez uczącego się,

- opierać się na wiedzy,

- $\quad$ wpływać na zwiększenie efektywności opanowania słownictwa i posługiwania się nim.

Zagadnieniami związanymi ze strategiami, jakie uczący się wykorzystują, opanowując leksykę, zajmowano się już wcześniej (Rubin, 1975; Oxford, 1990; O'M alley, Chamot, 1990), lecz były one włączane w ogólny nurt badań nad strategiami uczenia się języka obcego. Tematyka ta stała się odrębnym obszarem badawczym za sprawą Schmitta, który w 1997 roku opracował pierwszą gruntowną taksonomię strategii uczenia się słownictwa oraz kwestionariusz Vocabulary Learning Strategies Questionnaire (VLSQ). Taksonomia ta opiera się na koncepcji Oxford (1990), jednak wprowadzono do niej modyfikacje wynikające ze specyfiki materiału językowego, jakim jest leksyka. Schmitt zwrócił uwagę na konieczność podziału działań podejmowanych przez uczących się nie tylko w zależności od ich rodzaju, lecz także od fazy obcowania z nowym wyrazem. Uczący się muszą najpierw ustalić, co dane słowo znaczy (faza I), następnie spróbować je zapamiętać (faza II) i dopiero wówczas zastosować taktyki umożliwiające opanowanie umiejętności aktywnego posługiwania się nim w aktach komunikacji (faza III). Strategie uczenia się słownictwa obcojęzycznego dzielą się więc na strategie:

(I) ułatwiające ustalenie znaczenia,

(II) wspomagające zapamiętywanie,

(III) pozwalające na monitoring postępów w nauce.

W celu ułatwienia ustalenia znaczenia nowego słowa uczący się stosują strategie poznawcze, które obejmują strategie indywidualne oraz społeczne. Pierwsze odnoszą się do działań, jakie wykorzystują samodzielnie, aby ustalić znaczenie danego słowa (np. analizują budowę danego słowa, analizują kontekst, szukają znaczenia nowego słowa w słowniku). Drugie - to działania o charakterze interakcyjnym podejmowane przez nich w celu ustalenia, co dane słowo znaczy (np. pytania o znaczenie kierowane do nauczyciela, kolegów i koleżanek lub rodziców). Stosowanie tych strategii jest uzależnione od poziomu kompetencji ogólnych oraz umiejętności językowych uczących się.

Kolejnym etapem jest zapamiętanie nowego słowa. Pomocne w tym zakresie są strategie konsolidacyjne, wspomagające proces zapamiętywania nowych informacji i pozwalające na monitoring postępów. W ich zakres wchodzą strategie pamięciowe, kognitywne i społeczne. Pierwsze, wspierają proces wbudowania nowych informacji w obręb struktur poznawczych uczącego się i obejmują takie 
działania, jak np. skojarzenia, grupowanie wyrazów, łączenie znaczenia z wyrazem, techniki mnemotechniczne. Podczas gdy strategie kognitywne odnoszą się do procedur utrwalających nowe informacje, np. poprzez stosowanie powtórzeń ustnych i pisemnych lub tworzenie listy słów czy fiszek językowych, strategie społeczne obejmują działania o charakterze interakcyjnym, np. uczenie się i ćwiczenie w grupie, kontakt z rodzimymi użytkownikami języka w celu poznawania i aktywizowania poznanego słownictwa.

Dobór strategii jest uzależniony m.in. od czynników indywidualnych, zewnętrznych (społecznych) i zadaniowych (Seretny, 2015: 243 i 248), nie istnieje bowiem żadna sprawdzona procedura użycia strategii, której stosowanie zagwarantowałoby sukces edukacyjny. Do grupy czynników indywidualnych zalicza się m.in.: osobow ość uczącego się, jego wiek, płeć, motywację i samoocenę, znajomość innych języków, tło kulturowe, poziom wiedzy pozajęzykowej, style uczenia się i modalność, preferencje kulturowe. Czynniki zewnętrzne dotyczą z kolei sposobu prezentacji nowego materiału i technik nauczania, bogactwa materiałów wyjściowych, środowiska uczącego się (endolub egzolingwalnego), charakteru materiału, który uczący się muszą opanować. Trzecią grupą czynników są te związane z określonym zadaniem: z jego typem, stopniem skomplikowania, poziomem ogólności lub kognitywnej złożoności (Seretny, 2015: 248).

\section{Osobowość i sposoby jej pomiaru}

W ujęciu Pervina (2002) osobowość jest złożoną strukturą, obejmującą całość myśli, emocji, zachowań, nadającą kierunek i wzorzec ludzkiemu życiu. Stanowi ona zespół procesów odzwierciedlających działanie natury (geny), środowiska i kultury. Swoim zasięgiem obejmuje przy tym wszystkie perspektywy czasowe: wspomnienia, reprezentacje mentalne teraźniejszości, wyobrażenia i oczekiwania dotyczące przyszłości.

Osobowość, jej rozwój i sposoby kształtowania są przedmiotem zainteresowania wielu grup społecznych, np. rodziców, nauczycieli, polityków, a także wielu dyscyplin naukowych, wśród nich m.in. pedagogiki, psychologii, socjologii, politologii. Największe znaczenie osobow ość odgrywa w psychologii, gdzie stała się jednym z kluczowych pojęć, dotyczy bowiem procesów psychicznych zachodzących w jednostce (Wysocka, 2004: 938-939).

Pomimo że od lat 30. XX wieku prowadzone są badania nad osobowością, do dziś nie opracowano jednej spójnej definicji tego pojęcia. Różnorodność i wielość definicji wynika stąd, że autorzy pod pojęciem osobowość starają się wyjaśnić różne zjawiska. We współczesnych badaniach nad osobowością można wyróżnić trzy główne podejścia. W pierwszym z nich punktem wyjścia 
są różnice indywidualne. Badacze starają się uzyskać odpowiedź na pytanie: Dlaczego ludzie w sposób systematyczny różniq się między sobq w pewnych sferach? Drugie podejście koncentruje się na założeniu, że zachowanie ludzi charakteryzuje pewna stałość. Celem badań jest tu wyjaśnianie czynników, które tę stałość warunkują. Przyjmuje się przy tym, że stałość zachowania jest wynikiem istnienia specyficznych struktur wewnętrznych, tzw. cech psychicznych, których zespół stanowi właśnie osobow ość. W podejściu trzecim osobowość postrzegana jest jako mechanizm, który warunkuje organizację i kierunkowość zachowania jednostek (Wysocka, 2004: 939).

W podejściach ukierunkowanych na badanie problematyki osobowości ludzkie działanie jest analizowane z dwóch różnych perspektyw: stałości i zmienności. Psychologia osobowości zajmuje się tym samym wykrywaniem praw ogólnych (uśrednianiem) i określaniem różnic indywidualnych (Wysocka, 2004: 939). Metodą badania osobowości jest kwestionariusz (inwentarz) osobowości. Jest to poddany zabiegom standaryzacji i normalizacji zestaw pytań i twierdzeń wskaźnikowych. Odwołuje się on do samowiedzy i samoopisu, czyli wiedzy jaką posiada badany na temat samego siebie. Pozwala on opisać osobowość jednostki w sposób kompleksowy i zgodny z przyjętą koncepcją. Punktem wyjścia jest założenie, że człowiek w ciągu swojego życia i kontaktów zotoczeniem gromadzi pewną wiedzę na swój temat. Jest świadomy m.in. sposobów swojego postępowania, zachowania w danych sytuacjach, własnych preferencji czy wartości. Osoba badana odgrywa przy tym różnorodne role. Jest nie tylko uczestnikiem badania, lecz także obserwatorem, który rejestruje fakty i dokonuje ich interpretacji (Wysocka, 2003: 426-427). Sposób zbierania informacji za pomocą inwentarza osobowości ma cechy wspólne z techniką wywiadu standaryzowanego. Różnica dotyczy ujednolicenia formy odpowiedzi, których może udzielić osoba badana.

Pierwszy inwentarz osobowości został skonstruowany w 1906 roku przez psychologów holenderskich, Heymansa i Wiersma, prowadzących badania nad temperamentem. Po dwudziestu pięciu latach od tego czasu nastąpił rozkwit badań kwestionariuszowych, które w zmodyfikowanej formie są wykorzystywane do dziś (np. Eysenck, 1967; Cattel, 1971; Hathaway, 1982)2.

Metoda kwestionariuszowa nie jest doskonała, gdyż jest podatna na świadome bądź nieświadome manipulacje przez osoby badane. Zastrzeżenia mogą dotyczyć m.in. (Wysocka, 2003: 430-431):

\footnotetext{
${ }^{2}$ Pojęcie inwentarza i kwestionariusza bywa w literaturze rozróżniane ze względu na kryterium liczby zmiennych, która ma być poddana ocenie. Kwestionariusz służy do badania pojedynczych cech osobowości, inwentarz zaś to kwestionariusz wieloczynnikowy (Sanocki, 1981).
} 
Analiza korelacji pomiędzy nasileniem cech osobow ości a strategiami uczenia się...

- wieloznaczności pytań, a przez to subiektywnego ich znaczenia dla badanych i sposobu auto-interpretacji,

- ludzkiej tendencji do przekształcania i/lub wypierania faktów na swój temat,

- świadomego zatajania lub zniekształcania informacji na swój temat.

\section{Przegląd literatury}

Znaczna część badań poświęconych strategiom uczenia się języków obcych koncentruje się na uwarunkowaniach dotyczących ich użycia. Zakłada się, że ich stosowanie przez uczących się jest determinowane przez szereg różnic indywidualnych (Oxford, Nyikos, 1989; Ehrman, Oxford, 1990; Wakamoto, 2000). Wyniki dotychczasowych badań wskazują również, że istotne różnice w wyborze strategii obserwuje się w odniesieniu do typów osobowości (wymiar ekstrawersja vs introwersja oraz wymiar decydowanie vs postrzeganie) (Ehrman, Oxford, 1990, 1995; Wakamoto, 2000; Liyange, 2004; Sharp, 2009). W tych badaniach pomiaru osobowości dokonywano za pomocą kwestionariusza Myers-Briggs Type Indicator (MBTI), który ujmuje ludzką osobowość w szesnaście typów. Ze względu na zastrzeżenia co do rzetelności i trafności tego narzędzia, uzasadnione wydają się wątpliwości dotyczące faktycznej wartości poznawczej opisywanych wyżej badań (Zmbardo, Johnson, M cCann, 2010: 48).

Prowadzone były również badania poświęcone związkom pomiędzy cechami osobowościowymi uczących się a deklarowanymi strategiami uczenia się, które wykorzystują do opisu osobowości kwestionariusz Eysencka (EPQ). Pozwala on na jej diagnozę w oparciu o model PEN obejmujący trzy wymiary: psychotyczność, ekstrawersję i neurotyczność. Dotychczasowe badania sugerują istotny związek pomiędzy poziomem ekstrawersji a korzystaniem z określonych grup strategii (w odniesieniu do kwestionariusza strategii uczenia się języków obcych (SILL) autorstwa Oxford) (Liyanage, Bartlett, 2013).

W celu bardziej szczegółowego opisu osobowości uczących się stosuje się kwestionariusze reprezentujące podejście oparte na teorii cech. Powszechnie uznaną współczesną koncepcją ujmującą osobowość w kategoriach cech jest tzw. pięcioczynnikowy model osobowości (Zawadzki i in., 1998). Jednym z najnowszych narzędzi diagnozy cech jest zaś inwentarz NEO-FFI, umożliwiający diagnozę osobowości w zakresie jej pięciu podstawowych wymiarów: neurotyczności, ekstrawersji, otwartości na doświadczenie, ugodowości i sumienności.

Na przestrzeni lat w licznych badaniach próbowano też zidentyfikować osobowościowe korelaty osiągnięć edukacyjnych (O'Connor, Paunonen, 2007; Ackerman, Chamorro-Premuzic, Furnham, 2011; Heaven, Ciarrochi, 2012). Badacze wskazują na otwartość, doświadczenie oraz sumienność jako wymiary osobowości, które w największym stopniu wpływają na proces uczenia się. 
Najsilniejszym predyktorem osiągnięć edukacyjnych na różnych etapach nauki okazała się sumienność. Stwierdzono również, że z sukcesem w nauce języków obcych negatywnie koreluje wysoki poziom ekstrawersji; ujemną korelację z osiągnięciami w nauce wykazuje także neurotyczność z powodu czynnika lękowego (Dörnyei, Ryan, 2015: 25-26).

Na gruncie polskim prowadzono niewiele badań poświęconych zależnościom pomiędzy stosowaniem strategii uczenia się języków a cechami osobowości rozpatrywanymi w oparciu o model pięcioczynnikowy. Na uwagę zasługują analizy dotyczące powiązań występujących między stosowaniem strategii uczenia się języka angielskiego przez grupę studentów Uniwersytetu im. Adama Mickiewicza oraz Wyższej Szkoły Bankowej w Poznaniu a szeregiem zmiennych indywidualnych, m.in. osobow ością rozumianą zgodnie z paradygmatem pięcioczynnikowym (Przybył, 2017). W badaniu tym zastosowano polską adaptację Inwentarza Osobowości NEO-FFI (Zawadzki i in., 1998) oraz polską wersję kwestionariusza strategii uczenia się języków obcych SILL (Oxford, 1990). Wyniki pokazały istnienie umiarkowanie silnych, istotnych statystycznie korelacji pomiędzy poziomem otwartości na doświadczenie a częstością stosowania strategii uczenia się jako takich oraz pomiędzy poziomem otwartości na doświadczenie a częstością użycia strategii kognitywnych (Przybył, 2017: 98). Ponadto dowiedziono, że studentów rzadko stosujących strategie uczenia się cechuje stosunkowo niski poziom otwartości na doświadczenie oraz relatywnie niski poziom ekstrawersji, natomiast osoby często wykorzystujące strategie wykazują względnie wysokie nasilenie obu tych cech (Przybył, 2017: 99).

$\mathrm{Na}$ podstawie analizy literatury przedmiotu można uznać, że wiele aspektów roli osobowości w kontekście wykorzystywanych strategii uczenia się języków obcych w dalszym ciągu pozostaje niejasna, zaś wnioski płynące z dotychczasowych badań charakteryzują się sporym poziomem ogólności.

\section{Projekt badawczy}

\subsection{Hipoteza i pytania badawcze}

Analiza literatury przedmiotu na temat związków cech osobowościowych uczących się z użyciem strategii uczenia się języków obcych przyczyniła się do postawienia następującej hipotezy badawczej:

Wybór strategii/grupy strategii uczenia się słownictwa obcojęzycznego jest skorelowany z natężeniem różnych cech uczq̨cego się w zakresie poszczególnych wymiarów osobowości. 
Główne pytanie badawcze brzmiało zaś:

Czy istnieje statystycznie istotna zależność pomiędzy osobowościq badanych w obrębie poszczególnych wymiarów ujętych w modelu pięcioczynnikowym a wybieranymi (preferowanymi) strategiami uczenia się niemieckiego słownictwa?

Pytania uzupełniające zostały sformułowane następująco:

Które cechy i w jakim stopniu korelują z wyborem danej grupy strategii? Jak nasilenie poziomu danej cechy w zakresie poszczególnych skal wpływa na częstość stosowania danej strategii/grupy strategii?

\subsection{Uczestnicy badania}

Grupę badawczą stanowiło 42 abiturientów, uczących się języka niemieckiego jako drugiego języka obcego po angielskim i przystępujących w 2021 roku do matury zjęzyka niemieckiego na poziomie podstawowym i rozszerzonym. Dwudziestu z nich to uczniowie XI Liceum Ogólnokształcącego im. M ikołaja Reja w Warszawie. Pozostali to uczniowie z Zespołu Szkół im. K. C. M rongowiusza w Olsztynku. W badaniu uczestniczyło 42 respondentów: 23 kobiety oraz 19 mężczyzn.

\subsection{Narzędzia badawcze}

W celu udzielenia odpowiedzi na pytania badawcze wykorzystano dwa narzędzia badaw cze:

- polską wersję kwestionariusza strategii uczenia się słownictwa VLSQ (Schmitt, 1997),

- polską adaptację Inwentarza Osobowości NEO-FFI (Zawadzki i in., 1998).

W badaniach nad użyciem strategii uczenia się słownictwa niemieckiego wykorzystano kwestionariusz autorstwa Schmitta (1997) Vocabulary Learning Strategies Questionnaire (VLSQ), przetłumaczony na język polski (zob. Seretny, 2015), w którym, jak wspomniano, wydzielono trzy grupy strategii:

- ułatwiające ustalenie znaczenia (indywidualne/społeczne),

- wspomagające zapamiętywanie (pamięciowe/kognitywne),

- pozwalające na monitoring postępów w nauce (metakognitywne). 
Przed przystąpieniem do wypełniania kwestionariusza badani zostali zapoznani z instrukcją, zgodnie z którą po uważnym przeczytaniu danego stwierdzenia należało zaznaczyć takie strategie, które badany/a rzeczywiście stosuje, określając, w jakim stopniu dana strategia odnosi się do niego/niej. W teście badani znaleźli stwierdzenia typu:

Gdy nie wiem, co dane słowo znaczy, to:

1. analizuję jego budowę (temat, prefiksy itp.), szukajqc znajomych części

2. staram się ustalić, jaka to część mowy (rzeczownik, przymiotnik...)

3. zastanawiam się, czy nie ma w moim języku ojczystym słowa, które brzmi podobnie... itd.

Badani przypisali wymienionym działaniom strategicznym odpowiednią wartość, posługując się pięciostopniową skalą Likerta: nigdy tak nie robię (1), raczej tak nie robię (2), czasem tak robię (3), często tak robię (4), zawsze tak robię (5). Badanie zostało przeprowadzone z wykorzystaniem platformy PROFITEST do tworzenia profesjonalnych testów i ankiet ${ }^{3}$.

Jednym z wielu kwestionariuszy pozwalających dokonać kompleksowej charakterystyki osobowości wedle przyjętej koncepcji jest Kwestionariusz Osobowości NEO-FFI (ang. NEO Five Factor Inventory) opracowany przez Costę i McCrae (1992). Podczas badania została wykorzystana polska adaptacja inwentarza osobowości NEO-FFI autorstwa Zawadzkiego, Strelaua, Szczepaniaka i śliwińskiej (1998). Narzędzie to jest rekomendowane przez Pracownię Testów Psychologicznych Polskiego Towarzystwa Psychologicznego. Pozycje kwestionariusza NEO-FFI odnoszą się do 60 twierdzeń o charakterze samoopisowym. Badany ocenia ich prawdziwość na skali pięciostopniowej. Badanie było przeprowadzane bez ograniczenia czasu (średni czas badania wynosił 15 minut). Test został przeprowadzony w formie e-badania dostępnego na platformie Epsilon ${ }^{4}$.

\subsection{Procedura analizy danych}

Uzyskane dane poddano analizie ilościowej, w ramach której przeprowadzono pomiar korelacji Pearsona oraz analizy wariancji, regresji krokowej i regresji wielokrotnej. Współczynnik r korelacji Pearsona określa poziom zależności liniowej pomiędzy zmienną niezależną (nasilenie danej cechy osobowości)

\footnotetext{
${ }^{3} \mathrm{https://profitest.pl/}$

${ }^{4}$ Zakup licencji umożliwiającej realizację badania został dokonany przez psychologa dr. Sokołowskiego, pracownika Centrum Kształcenia Nauczycieli Języków Obcych i Edukacji Europejskiej Uniwersytetu Warszawskiego. Sprawował on zarówno merytoryczny, jak i formalny nadzór nad badaniem.
} 
a zmienną zależną (częstotliwość stosowania strategii uczenia się słownictwa). Przyjmuje on wartość z przedziału [-1, 1]. Znak współczynnika korelacji informuje o kierunku korelacji (korelacja dodatnia lub ujemna). Jeżeli r jest dodatnie, wówczas wraz ze wzrostem jednej zmiennej wzrastają wartości drugiej. Jeśli r jest ujemne, to wraz ze wzrostem jednej zmiennej, druga ma tendencję do zmniejszania się. Wartość bezwzględna współczynnika $r$ informuje o sile związku. Im bardziej $r$ jest oddalone od zera, tym silniejsza jest liniowa zależność między dwiema zmiennymi.

Analiza wariancji pozwala na zbadanie zależności pomiędzy wartościami zmiennej zależnej a zespołem predyktorów. Analiza regresji krokowej umożliwia wprowadzenie do modelu tylko te zmienne, predyktory, które istotnie przewidują zmienną zależną. Analiza regresji wielokrotnej dla wpływu zespołu predyktorów na zmienną zależną pozwala na uzyskanie współczynnika determinacji określającego, w jakim stopniu zbudowany model regresji wyjaśnia zmienność zmiennej zależnej. Zmienność tę określa się procentowo.

\section{Wyniki badania}

\subsection{Badanie inwentarzem NEO-FFI}

Uzyskane w toku badania wyniki surowe zostały zinterpretowane w oparciu o 10stopniową skalę stenową, której skrajne wartości (1 i 10) odpowiadają przeciwległym biegunom każdej z pięciu skal. Przyjmuje się, że wyniki mieszczące się w granicach od 1 do 3 stena można interpretować jako wyniki niskie. Wyniki zawierające się w przedziale od 7 do 10 stena są traktowane jako wysokie, natomiast wyniki przyjmujące wartości od 4 do 6 stena uznaje się za zrównoważone.

\section{Neurotyczność (NEU)}

Pierwszą z badanych cech osobowości uczących się była neurotyczność. Na dwóch przeciwległych biegunach znajdują się: przystosowanie emocjonalne versus emocjonalne niezrównoważenie. W grupie badanych ponad połowa miała podwyższony poziom cech neurotycznych. Osoby o dużym nasileniu tej cechy są osobami wrażliwymi, emocjonalnymi, skłonnymi do napięć i martwienia się. Z kolei u 40,47\% badanych stwierdzono zrównoważone cechy w tym wymiarze, co oznacza, że osoby te są ogólnie spokojne i zrównoważone, ale czasami doświadczają gniewu, smutku i poczucia winy.

\section{Ekstrawersja (EKS)}

Kolejną mierzoną cechą osobowości uczących się była ekstrawersja. Podczas gdy $19,04 \%$ badanych miało wysoki poziom cech ekstrawertycznych, to $8,1 \%$ 
spośród nich osiągnęło jej niski poziom. Najwięcej było osób o zrównoważonych cechach (42,86\%). Są one przeciętne pod względem towarzyskości i aktywności, lubiące kontakty z innymi ludźmi.

\section{Otwartość na doświadczenie (OTW)}

Trzecią badaną grupą cech była otwartość na doświadczenie. 29\% badanych wykazuje cechy dużej otwartości na doświadczenie. Są to osoby ciekawe świata, kreatywne, o szerokich zainteresowaniach, mające żywą i twórczą wyobraźnię. Połowa badanych (50\%) otrzymała przeciętny wynik testów w tym wymiarze. Natomiast $21,42 \%$ badanych charakteryzowała się małą otwartością na doświadczenie. Osoby te są konwencjonalne w zachowaniu i konserwatywne w poglądach.

\section{Ugodowość (UGD)}

Ugodowość jest cechą osobowości opisującą m.in. pozytywne nastawienie do innych ludzi. Około 40,48\% badanych ma wysoki wynik w tym wymiarze. Są to osoby sympatyczne i skłonne do udzielania innym pomocy. W badanej grupie połowa badanych ma przeciętny wynik cech ugodowości. Są to osoby ogólnie miłe i przyjazne, ale czasami mogą wykazywać zainteresowanie rywalizacją. W badanej grupie nie zabrakło też osób mało ugodowych - ok. 10\%.

\section{Sumienność (SUM)}

Ostatnią badaną cechą jest sumienność. Mówi ona m.in. o ukierunkowaniu jednostki na realizację założonych przez siebie celów oraz jej stosunku do pracy. 30\% badanych to osoby o dużej sumienności. Około połowa badanych posiadała zrównoważone cechy w zakresie sumienności. Natomiast osoby o stosunkowo niskim poziomie sumienności stanowiły $21,43 \%$ badanych.

\subsection{Badanie kwestionariuszem strategii uczenia się słownictwa (N. Schmitt, 1997)}

Uzyskane wyniki pozwalają stwierdzić, wbrew przewidywaniom, że badani rzadko stosują strategie społeczne, metakognitywne i pamięciowe, częściej sięgają zaś po strategie z grupy strategii indywidualnych i kognitywnych.

W grupie strategii indywidualnych najczęściej wymienianymi sposobami pozwalającymi ustalić znaczenie nieznanej jednostki leksykalnej okazały się: analiza kontekstu nowego słowa oraz poszukiwanie słów brzmiących/wyglądających podobnie w języku polskim (ryc. 1). 
Analiza korelacji pomiędzy nasileniem cech osobow ości a strategiami uczenia się...

\begin{tabular}{|c|c|}
\hline \multicolumn{2}{|l|}{ STRATEGIE INDYWIDUALNE } \\
\hline Gdy nie wiem, co dane niemieckie słowo znaczy to: & $\begin{array}{c}\text { Średnia częstość } \\
\text { stosowania } \\
\text { strategii }\end{array}$ \\
\hline zastanawiam się nad jego znaczeniem tylko wtedy, gdy brzmi dziwnie & 1,6 \\
\hline sprawdzam jego znaczenie w słowniku niemiecko-niemieckim (np. DUDEN) & 2,6 \\
\hline sprawdzam jego znaczenie w słow niku niemiecko-polskim (np. PONS) & 2,7 \\
\hline staram się ustalić, jaka to część mowy (czasownik, rzeczownik itd.) & 3,3 \\
\hline sprawdzam jego znaczenie wtedy, gdy spotykam je któryś raz & 3,4 \\
\hline nie zwracam na nie uwagi, jeśli mniej więcej rozumiem komunikat & 3,4 \\
\hline $\begin{array}{l}\text { analizuję jego budowę (temat, prefiksy itp.), szukając znajomych części (np. Freund, } \\
\text { Freundin, Freundschaft, sich befreunden, freundlich...) }\end{array}$ & 3,6 \\
\hline nie zastanawiam się nad tym, chyba że wydaje mi się to słowo ważne & 3,6 \\
\hline sprawdzam jego znaczenie wtedy, gdy wydaje mi się częste & 3,7 \\
\hline nie zastanawiam się nad tym, chyba że pyta o nie nauczyciel & 3,8 \\
\hline zastanawiam się nad jego znaczeniem tylko wtedy, gdy dziwnie wygląda & 3,9 \\
\hline sprawdzam jego znaczenie wtedy, gdy pyta o nie nauczyciel & 3,9 \\
\hline sprawdzam jego znaczenie wtedy, gdy pojawia się w ćwiczeniach & 3,9 \\
\hline analizuję jego kontekst (obrazy, gesty, inne słowa) & 4,1 \\
\hline $\begin{array}{l}\text { zastanawiam się, czy nie ma w języku polskim słowa, które brzmi podobnie (np. Kino, } \\
\text { Radio, Lampe itp.) }\end{array}$ & 4,2 \\
\hline
\end{tabular}

Ryc. 1: Średnia częstość stosowania strategii indywidualnych ułatwiających ustalenie znaczenia (w skali od 1 do 5).

W grupie strategii pozwalającej/ułatwiającej ustalić znaczenia słowa są również strategie społeczne; były stosowane czasami w zakresie prośby o przetłumaczenie przez nauczyciela czy zapytanie koleżanki/kolegi o znaczenie (ryc. 2).

\begin{tabular}{|l|c|}
\hline \multicolumn{2}{|c|}{ STRATEGIE SPOtECZNE } \\
\hline Gdy nie wiem, co dane niemieckie słowo znaczy to: & $\begin{array}{c}\text { Średnia } \\
\text { częstotliwość } \\
\text { stosowania } \\
\text { strategii }\end{array}$ \\
\hline pytam o znaczenie tego słowa mamę/tatę/członka rodziny & 1,5 \\
\hline proszę nauczyciela o zbudowanie zdania z nowym wyrazem & 1,8 \\
\hline proszę nauczyciela o synonim lub wyjaśnienie w języku niemieckim & 2,2 \\
\hline próbuję ustalić znaczenie tego słowa, rozmawiając z kolegami/koleżankami w grupie & 2,2 \\
\hline dowiaduję się, co znaczy dane słowo, dzięki pracy w grupie & 2,4 \\
\hline proszę nauczyciela o przetłumaczenie tego słowa na język polski & 3,1 \\
\hline pytam o znaczenie tego słowa kolegę/koleżankę & 3,2 \\
\hline
\end{tabular}

Ryc. 2: Średnia częstość stosowania strategii kognitywnych ułatwiających ustalenie znaczenia (w skali od 1 do 5).

Kolejna faza opanowania słownictwa obcojęzycznego obejmuje strategie wspomagające zapamiętywanie - pamięciowe i kognitywne. Badani podawali, że najczęściej wykorzystują strategie zestawienia nowych słów w języku niemieckim z podobnym słowem w polskim, zapamiętują, jak się dane słowo 
zapisuje, wymawia czy odmienia, a także łączą słowa tematycznie oraz zapamiętują nowe słowo z kontekstem, w którym się ono pojawia. Wbrew oczekiwaniom badani nie stosowali strategii mnemotechnicznych lub stosowali je bardzo rzadko (ryc. 3).

\section{STRATEGIE PAMIĘCIOWE}

Gdy chcę zapamiętać znaczenie nowego niemieckiego słowa to: Średnia częstość stosowania strategii

podkreślam pierwszą literę słowa 1,5

wykorzystuję mnemotechnikę „kołka” („haka”) 1,6 robię mapy znaczeniowe słów (w formie map myśli) 1,6

uczę się słów hierarchicznie (np. Tier - Haustier - Hund - M ischling) 1,8

jeśli się da, zapisuję wyrazy na skali, np. zimny - letni - ciepły - gorq̨cy wykorzystuję mnemotechnikę „miejsca” (np. pałac pamięci) podkreślam trudne kombinacje liter w pisowni słowa tworzę historyjkę z nowym wyrazem/nowymi wyrazami 1,8 1,8 1,9 2,0 posługuję się zestawieniami cech semantycznych, np. der Tisch (stół) = die Platte (blat), 4 Beine (nogi) itp. parafrazuję sobie znaczenie słowa (np. die Umwelt =M enschen, Tiere, Pflanzen...) staram się połączyć doznanie fizyczne/zmysłowe (np. smak, zapach) z danym słowem łączę znaczenie słowa z ruchem, który wykonuję wykorzystuję metodę „słów kluczy” nie uczę się pojedynczych wyrazów, lecz całych fraz, zwrotów, zdań zapisuję słowa w specjalny sposób, robię schematy, używam symboli $\rightarrow_{,} \neq$itp. staram się wyobrazić sobie formę/kształt słowa łączę to słowo z jego antonimem i/lub synonimem buduję zdanie z nowym wyrazem zapamiętuję słowa, tworząc skojarzenia, np. der Vogel (ptak), fliegen (latać), der Flügel (skrzydło) itp. zapamiętuję, jaką częścią mowy jest dane słowo (np. rzeczownikiem, czasownikiem, przymiotnikiem)

grupuję słowa, żeby się ich uczyć

zapamiętuję budowę słowa (temat, przedrostki, przyrostki), np. Vor-mittag, Wohn-ung itp. wyobrażam sobie znaczenie słowa (tworzę obraz słowa w pamięci) łączę znaczenie słowa z własnym doświadczeniem zapamiętuję słowo w zdaniu łączę znaczenie słowa z obrazem (patrzę na obrazek ilustrujący znaczenie) zapamiętuję nowe słowo wraz z kontekstem, w którym się pojawiło łączę nowe słowa tematycznie (z tymi, które już znam z danego tematu) zapamiętuję, jak się to słowo odmienia (np. lesen: ich lese, du liest, er/ sie/ es liest itd.) staram się zapamiętać, jak się to słowo wymawia staram się zapamiętać, jak się to słowo pisze zestawiam je z podobnym słow em w języku polskim (np. die Apotheke - apteka, das Theater - teatr)

2,0 2,0 2,1 2,3 2,5 2,5 2,5 2,5 2,6 2,6 2,7 2,7 2,8 2,8 2,9 2,9 2,9 3,0 3,1 3,1 3,5 3,9 4,0

Ryc. 3: Średnia częstość stosowania strategii wspomagających zapamiętywanie (w skali od 1 do 5). 
Analiza korelacji pomiędzy nasileniem cech osobow ości a strategiami uczenia się...

Do strategii wspomagających zapamiętywanie należą także strategie kognitywne (ryc. 4). Spośród strategii wspomagających zapamiętywanie największą popularnością cieszyły się: notowanie nowych słów, ich wielokrotne zapisywanie oraz kilkukrotne powtarzanie na głos. Rzadziej uczący się wymieniali uczenie się słów ze słowniczka w podręczniku czy tworzenie fiszek językowych.

\begin{tabular}{|l|c|}
\hline \multicolumn{2}{|c|}{ STRATEGIE KOGNITYWNE } \\
\hline Gdy chcę zapamiętać znaczenie nowego niemieckiego słowa to: & $\begin{array}{c}\text { Średnia } \\
\text { częstotliwość } \\
\text { stosowania strategii }\end{array}$ \\
\hline naklejam kartki z nowymi słowami w swoim pokoju & 2,1 \\
\hline robię listy wyrazów, które ciągle uzupełniam & 2,7 \\
\hline zapisuję niemieckie wyrazy w specjalnym zeszycie z odpowiednikami w języku polskim & 2,7 \\
\hline robię fiszki (tzw. "flash cards") & 3,0 \\
\hline uczę się słów ze słow niczka w podręczniku & 3,4 \\
\hline głośno powtarzam to słowo kilka razy & 3,6 \\
\hline zapisuję to słowo kilka razy & 3,8 \\
\hline notuję nowe wyrazy, które pojawiają się na lekcji niemieckiego & 3,9 \\
\hline
\end{tabular}

Ryc. 4: Średnia częstość stosowania strategii wspomagających zapamiętywanie (w skali od 1 do 5).

Ostatnią grupą strategii są strategie metakognitywne, które przez badanych były stosowane w bardzo ograniczonym zakresie (ryc. 5). średnia udzielonych odpowiedzi wskazuje, że uczący się czasem stosują tylko strategię regularnego powtarzania listy słów.

\begin{tabular}{|l|c|}
\hline \multicolumn{2}{|c|}{ STRATEGIE METAKOGNITYWNE } \\
\hline Gdy chcę sprawdzić, czy znam coraz więcej niemieckich słów to: & $\begin{array}{c}\text { Średnia częstość } \\
\text { stosowania } \\
\text { strategii }\end{array}$ \\
\hline dużo czytam i słucham w języku niemieckim & 2,0 \\
\hline regularnie powtarzam słownictwo, by sprawdzić, czy pamiętam & 2,3 \\
\hline $\begin{array}{l}\text { robię sobie regularne testy słownikowe (w formie papierowej lub z wykorzystaniem apli- } \\
\text { kacji w telefonie) }\end{array}$ & 2,4 \\
\hline staram się używać jak najwięcej nowo poznanych niemieckich słów w mówieniu i pisaniu & 2,4 \\
\hline regularnie powtarzam słowa w parach - wyraz niemiecki +wyraz polski & 3,1 \\
\hline
\end{tabular}

Ryc. 5: Średnia częstość stosowania strategii pozwalających na monitoring postępów (w skali od 1 do 5).

\subsection{Korelacje pomiędzy cechami osobowości a stosowaniem strategii uczenia się słownictwa}

Analizę korelacji pomiędzy osobowością uczących się a stosowanymi przez nich strategiami uczenia się słownictwa niemieckiego rozpoczęto od pomiaru 
korelacji pomiędzy poziomem poszczególnych cech osobowości a częstością stosowania strategii ogółem (ryc. 6). Wykazano dodatnią korelację na granicy istotności statystycznej między poziomem ekstrawersji a częstością stosowania strategii uczenia się ogółem. Dodatkowo występuje umiarkowanie silny związek pomiędzy poziomem sumienności a częstością stosowania strategii ogółem. W tej części analizy nie wykazano (wbrew oczekiwaniom) istotnej korelacji pomiędzy poziomem otwartości na doświadczenie a stosowaniem strategii ogółem. Na podstawie tych danych można więc stwierdzić, że osoby wykazujące stosunkowo wysoki poziom ekstrawersji oraz sumienności częściej wykorzystują strategie uczenia się słownictwa.

\begin{tabular}{|c|c|c|c|c|c|}
\hline \multicolumn{7}{|c|}{ Korelacje } \\
\hline Zmienna & NEU & EKS & OTW & UGD & SUM \\
\hline Strategie & $-0,1364$ & $\mathbf{0 , 2 8 4 2}$ & 0,0329 & 0,2384 & $\mathbf{0 , 2 9 8 2}$ \\
ogółem & $p=0,389$ & $p=0,068$ & $p=0,836$ & $p=0,128$ & $p=0,055$ \\
\hline
\end{tabular}

Ryc. 6: Wyniki analizy korelacji Pearsona - poziom cech osobowości a częstość stosowania strategii uczenia się słownictwa ogółem.

Następnie zbadano korelację pomiędzy nasileniem poszczególnych cech osobowości uczniów a częstością stosowania strategii w obrębie trzech głównych grup (odpowiadających kolejnym fazom obcowania z nowym słowem) (ryc. 7). Analiza pozwoliła wykazać silną pozytywną korelację między poziomem sumienności a wykorzystywaniem strategii ułatwiających ustalenie znaczenia oraz pomiędzy poziomem sumienności a częstością stosowania strategii wspomagających zapamiętywanie. Oznacza to, że uczniowie, których cechuje wyższy poziom sumienności, częściej wybierają strategie ułatwiające ustalenie znaczenia oraz wspomagające zapamiętywanie.

\begin{tabular}{|l|c|c|c|c|c|}
\hline \multicolumn{1}{|c|}{ Zmienna } & NEU & EKS & OTW & UGD & SUM \\
\hline $\begin{array}{l}\text { Strategie uła- } \\
\text { twiające ustale- } \\
\text { nie znaczenia }\end{array}$ & $\begin{array}{c}-0,1924 \\
p=0,222\end{array}$ & $\begin{array}{c}-0,0788 \\
p=0,620\end{array}$ & $\begin{array}{c}0,0032 \\
p=0,984\end{array}$ & $\begin{array}{c}0,1381 \\
p=0,383\end{array}$ & $\begin{array}{c}\mathbf{0 , 3 6 1 2} \\
p=0,019\end{array}$ \\
\hline $\begin{array}{l}\text { Strategie wspo- } \\
\text { magające zapa- } \\
\text { miętywanie }\end{array}$ & $\begin{array}{c}-0,1705 \\
p=0,280\end{array}$ & $\begin{array}{c}0,0622 \\
p=0,696\end{array}$ & $\begin{array}{c}0,0732 \\
p=0,645\end{array}$ & $\begin{array}{c}0,186 \\
p=0,238\end{array}$ & $\begin{array}{c}\mathbf{0 , 3 3 4 9} \\
p=0,030\end{array}$ \\
\hline $\begin{array}{l}\text { Strategie pozwa- } \\
\text { lające na moni- } \\
\text { toring postępów }\end{array}$ & $\begin{array}{c}-0,1434 \\
p=0,365\end{array}$ & $\begin{array}{c}0,0429 \\
p=0,787\end{array}$ & $\begin{array}{c}0,1692 \\
p=0,284\end{array}$ & $\begin{array}{c}0,1246 \\
p=0,432\end{array}$ & $\begin{array}{c}0,2267 \\
p=0,149\end{array}$ \\
\hline
\end{tabular}

Ryc. 7: Wyniki analizy korelacji Pearsona - poziom cech osobowości a częstość stosowania strategii w obrębie grup odpowiadających kolejnym fazom opanowania nowego słownictwa. 
Analiza korelacji pomiędzy nasileniem cech osobow ości a strategiami uczenia się...

W kolejnym etapie przeanalizowano związki pomiędzy nasileniem cech osobowości a wykorzystywaniem strategii w odniesieniu do pięciu grup strategii określających rodzaj działań podejmowanych przez uczących się (ryc. 8). Analiza wykazała silną pozytywną korelację między poziomem ekstrawersji, ugodowości i sumienności a częstością stosowania strategii kognitywnych. M ożna na tej podstawie wysunąć wniosek, że badani o wyższym natężeniu ekstrawersji, ugodowości i sumienności częściej wybierają strategie kognitywne.

\begin{tabular}{|l|c|c|c|c|c|}
\hline \multicolumn{7}{|c|}{ Korelacje } \\
\hline \multicolumn{1}{|c|}{ Zmienna } & NEU & EKS & OTW & UGD & SUM \\
\hline Strategie & $-0,2307$ & 0,2206 & 0,2256 & $-0,0797$ & 0,1902 \\
indywidualne & $\mathrm{p}=0,142$ & $\mathrm{p}=0,160$ & $\mathrm{p}=0,151$ & $\mathrm{p}=0,616$ & $\mathrm{p}=0,228$ \\
\hline Strategie & 0,0915 & 0,2841 & $-0,1727$ & 0,1466 & 0,1174 \\
Społeczne & $\mathrm{p}=0,565$ & $\mathrm{p}=0,068$ & $\mathrm{p}=0,274$ & $\mathrm{p}=0,354$ & $\mathrm{p}=0,459$ \\
\hline Strategie & $-0,1465$ & 0,1914 & 0,0413 & 0,1521 & 0,2503 \\
pamięciowe & $\mathrm{p}=0,355$ & $\mathrm{p}=0,225$ & $\mathrm{p}=0,795$ & $\mathrm{p}=0,336$ & $\mathrm{p}=0,110$ \\
\hline Strategie & $-0,121$ & $\mathbf{0 , 3 4 3 7}$ & 0,091 & $\mathbf{0 , 3 3 1 8}$ & $\mathbf{0 , 3 9 6 2}$ \\
kognitywne & $\mathrm{p}=0,445$ & $\mathrm{p}=0,026$ & $\mathrm{p}=0,567$ & $\mathrm{p}=0,032$ & $\mathrm{p}=0,009$ \\
\hline Strategie & $-0,1939$ & 0,1856 & 0,0792 & 0,2081 & 0,1467 \\
metakognitywne & $\mathrm{p}=0,219$ & $\mathrm{p}=0,239$ & $\mathrm{p}=0,618$ & $\mathrm{p}=0,186$ & $\mathrm{p}=0,354$ \\
\hline
\end{tabular}

Ryc. 8: Wyniki analizy korelacji Pearsona - poziom cech osobowości a częstość stosowania strategii indywidualnych, społecznych, pamięciowych, kognitywnych oraz metakognitywnych.

$\mathrm{Na}$ koniec sprawdzono, czy istnieją statystycznie istotne korelacje pomiędzy osobowością badanych uczniów w obrębie pięciu wymiarów a częstością stosowania wybranych strategii. Analiza wykazała istotną statystycznie pozytywną korelację między poziomem sumienności a częstością wykorzystywania przez uczących się map myśli (ryc. 9). Oznacza to, że uczniowie bardziej sumienni częściej stosują wspomniane mapy myśli.

\begin{tabular}{|c|c|c|c|c|c|}
\hline \multicolumn{5}{|c|}{ Korelacje } \\
\hline Zmienna & NEU & EKS & OTW & UGD & SUM \\
\hline \multirow{2}{*}{ Mapy myśli } & $-0,0667$ & $-0,0014$ & $-0,0837$ & $-0,0323$ & $\mathbf{0 , 3 2 6 4}$ \\
& $p=0,675$ & $p=0,993$ & $p=0,598$ & $p=0,839$ & $p=0,035$ \\
\hline
\end{tabular}

Ryc. 9: Wyniki analizy korelacji Pearsona - poziom cech osobowości a częstotliwość stosowania map myśli.

Został również stwierdzony statystycznie silny związek pomiędzy poziomem sumienności a stosowaniem strategii pamięciowej polegającej na grupowaniu słów pod względem znaczenia (ryc. 10). Uczniowie, którzy wykazują dużą sumienność częściej stosują tę strategię. 
Anna Jaroszewska, Piotr Milewski, Katarzyna Posiadała

\begin{tabular}{|l|c|c|c|c|c|}
\hline \multicolumn{7}{|c|}{ Korelacje } \\
\hline \multicolumn{1}{|c|}{ Zmienna } & NEU & EKS & OTW & UGD & SUM \\
\hline Grupowanie & 0,0176 & $-0,0188$ & 0,0446 & $-0,0993$ & $\mathbf{0 , 3 1 3 2}$ \\
stów & $p=0,912$ & $p=0,906$ & $p=0,779$ & $p=0,532$ & $p=0,043$ \\
\hline
\end{tabular}

Ryc. 10: Wyniki analizy korelacji Pearsona - poziom cech osobowości a częstość stosowania strategii polegającej na grupowaniu słów pod względem znaczenia.

W wyniku analizy regresji wielokrotnej dla wpływu zespołu predyktorów na strategię polegającą na stosowaniu fiszek w nauce słownictwa uzyskano współczynnik korelacji na poziomie 0,92 sugerujący istotną zależność stosowania tej strategii od ekstrawersji i ugodowości (ryc. 11). W wyniku tej samej procedury uzyskano współczynnik korelacji na poziomie 0,92 sugerujący istotną zależność stosowania fiszek od poziomu otwartości na doświadczenie i ugodow ości (ryc. 12). Współczynnik determinacji wielokrotnej na poziomie 84,3\% poddano korekcie w oparciu o liczebność grupy; ostatecznie model wyjaśnia 84\% zmienności stosowania strategii. Wobec tego badani uczniowie cechujący się dużym nasileniem ugodowości, ekstrawersji i otwartości na doświadczenie częściej sięgają po fiszki.

\begin{tabular}{|c|c|c|}
\hline \multicolumn{3}{|c|}{ Korelacje } \\
\hline Zmienna & EKS & UGD \\
\hline \multirow{2}{*}{ Fiszki } & 0,2308 & $\mathbf{0 , 3 6 6 7}$ \\
& $p=0,141$ & $p=0,017$ \\
\hline
\end{tabular}

Ryc. 11: Wyniki analizy korelacji Pearsona - poziom cech osobowości a częstość stosowania fiszek.

\begin{tabular}{|c|c|c|}
\hline \multicolumn{3}{|c|}{ Korelacje } \\
\hline Zmienna & OTW & UGD \\
\hline \multirow{2}{*}{ Fiszki } & 0,0191 & $\mathbf{0 , 3 6 7}$ \\
& $\mathrm{p}=0,904$ & $\mathrm{p}=0,017$ \\
\hline
\end{tabular}

Ryc. 12: Wyniki analizy korelacji Pearsona - poziom cech osobowości a częstość stosowania fiszek.

Ponadto istnieje statystycznie silny związek pomiędzy ugodowością a stosowaniem strategii metakognitywnej polegającej na tym, że uczący się robi sobie regularne testy słownikowe (ryc. 13). Przeprowadzona analiza regresji wielokrotnej dla wpływu zespołu predyktorów na częstość wykorzystywania testów słownikowych pozwoliła na uzyskanie współczynnika korelacji na poziomie 0,93, co sugeruje istotną zależność stosowania tej strategii od poziomu neurotyczności i ugodowości. Współczynnik determinacji wielokrotnej na poziomie $87 \%$ poddano korekcie w oparciu o liczebność grupy; ostatecznie model wyjaśnia $86 \%$ zmienności stosowania strategii. W oparciu o wartość 
Analiza korelacji pomiędzy nasileniem cech osobow ości a strategiami uczenia się...

tego współczynnika można stwierdzić, że badani uczniowie o wysokim poziomie ugodow ości i neurotyczności częściej robią sobie testy słownikowe celem kontroli postępów w nauce słownictwa.

\begin{tabular}{|c|c|c|}
\hline \multicolumn{3}{|c|}{ Korelacje } \\
\hline Zmienna & NEU & UGD \\
\hline \multirow{2}{*}{ Testy słownikowe } & $-0,1393$ & $\mathbf{0 , 3 2 0 1}$ \\
& $\mathrm{p}=0,379$ & $\mathrm{p}=0,039$ \\
\hline
\end{tabular}

Ryc. 13: Wyniki analizy korelacji Pearsona - poziom cech osobowości a częstość stosowania testów słownikowych.

\section{Dyskusja}

Uzyskane wyniki - ze względu na małą próbę 42 badanych - nie upoważniają do uogólnień, lecz ukazują jedynie pewne tendencje. Pozwalają wnioskować, że w badanej grupie maturzystów natężenie pewnych cech osobowości może wpływać na częstość stosowania strategii uczenia się słownictwa niemieckiego.

Najsilniejszym predyktorem stosowania strategii uczenia się słownictwa niemieckiego ogółem oraz strategii kognitywnych (które stanowią najczęściej stosowaną grupę strategii wśród badanych maturzystów), może być wysoki poziom sumienności i ekstrawersji. Oznacza to, że ci spośród badanych abiturientów, którzy są skrupulatni, dobrze zorganizowani, rzetelni i wytrwali w dążeniu do celów, relatywnie częściej wykorzystują ww. strategie. Uzyskane wyniki potwierdzają, że poziom sumienności uczących się może być uznawany za predyktor sukcesu w nauce języka obcego (por. (Dörnyei, Ryan, 2015). Podobnie jest w przypadku uczniów, którzy są z natury entuzjastami i optymistami, cechują się wysokim poziomem aktywności, często odczuwają potrzebę zaangażowania, poszukują zewnętrznej stymulacji i są bardziej skłonni do reagowania pozytywnymi emocjami. Nie należy jednak pomijać innych czynników osobowościowych, nawet jeśli nie wykazano w ich przypadku statystycznie istotnej korelacji. Jak pokazują wcześniejsze badania, na szczególną uwagę w kontekście stosowania strategii uczenia się języka może zasługiwać wymiar otwartości na doświadczenie (Przybył, 2017: 100). Biorąc pod uwagę zarówno wyniki badań korelacyjnych, jak i wnioski płynące z jakościowej analizy opisanych powyżej wymiarów osobowości można z dużą dozą prawdopodobieństwa stwierdzić, że różne natężenie poszczególnych cech może w mniejszym lub większym stopniu predysponować do stosowania strategii uczenia się.

O powodzeniu w nauce języka nie musi decydować jednak wyłącznie częstość stosowania strategii. Kluczowe znaczenie mają również aspekty jakościowe. Istotne jest, by repertuar strategii mógł być dostosowany do indywidualnego profilu uczącego się (Pawlak, 2019: 8). W związku z tym zasadniczym 
celem działań nauczyciela powinno być zapoznanie uczniów z jak najszerszą gamą strategii uczenia się języka. Dlatego wskazane jest włączenie do programu zajęć języka obcego kompleksowego treningu strategicznego, który spełniałby określone kryteria jakościowe. Jak wynika z literatury przedmiotu, dobrze zaplanowany i przeprowadzony trening strategii powinien mieć określoną strukturę, tj. obejmować następujące po sobie fazy:

- identyfikacja wykorzystywanych przez uczniów strategii;

- prezentacja alternatywnych strategii;

- wypróbowanie przez uczniów nowo wprowadzonych strategii;

- ćwiczenia obejmujące stosowanie wybranych strategii w działaniu;

- ewaluacja.

(Viebrock, 2010: 223)

Tak pomyślany trening, którego celem jest wyposażenie uczących się w jak najszerszy zestaw odpowiednich strategii, umożliwiający im planowanie, monitorowanie i poddawanie refleksji własnego procesu uczenia się języka, zarówno w klasie, jak i poza nią, należy uznać za rodzaj innowacji programowej, której właściwe wdrożenie wymaga od nauczyciela indywidualnego podejścia do ucznia.

Wychodząc z założenia, że stosowane strategie uczenia się języka stanowią zmienną pośredniczącą pomiędzy osobowością uczącego się a osiągnięciami w nauce języka obcego, można wysnuć wniosek, że wyjaśnienie związku między osobowością a preferowanymi strategiami uczenia się mogłoby istotnie przyczynić się do optymalizacji procesu kształcenia językowego. W dalszym ciągu jednak szereg pytań badawczych w zakresie osobowościowych uwarunkowań stosowania strategii uczenia się języka pozostaje otwartych. Aby móc na nie odpowiedzieć, warto, planując kolejne badania empiryczne w tym zakresie, łączyć podejścia metodologiczne i uzyskane wyniki ilościowe wzbogacać analizą jakościową.

\section{Zakończenie}

Osobowość jest strukturą, którą trudno jest badać i interpretować. Wynika to z jej złożoności oraz różno rodności czynników, które wpływają na jej rozwój. Badanie osobowości dla badacza nie będącego z wykształcenia psychologiem jest wyzwaniem nie tylko teoretycznym, koncepcyjnym, metodologicznym, lecz także organizacyjnym i finansowym. Tymczasem wiedza na temat osobowości, a także znajomość metodologii w tym zakresie w znaczący sposób może pomóc nauczycielowi (języka obcego) w doskonaleniu warsztatu pracy, w zbadaniu i zrozumieniu potrzeb i preferencji uczeniowych jego podopiecznych. 
Nauczyciel języka obcego, niezależnie od pełnionych funkcji i nałożonych nań w szkolnej rzeczywistości różnorodnych zadań, sam decyduje o kierunku podejmowanych kroków dydaktycznych i wychowawczych oraz sposobie osiągania zakładanych celów. Dopasowuje je do specyficznych właściwości ucznia i do jego potrzeb. Uczeń zaś, który dzięki działaniom nauczyciela ma możliwość uświadomienia sobie swoich cech i preferencji w odniesieniu do procesu uczenia się języka obcego, który ma możliwość uczestniczenia w treningu strategii, a więc ich poznania i zastosowania, staje się uczniem świadomym i refleksyjnym. Trening strategii wraz z badaniami poświęconymi ich wykorzystaniu w nauce języka obcego w powiązaniu z badaniem czynników osobowości stanowi cenne źródło wiedzy o sobie i swoich preferencjach, mocnych i słabszych stronach w tym zakresie. Oba podmioty procesu nauczania i uczenia się języka obcego, a więc nauczyciel i uczeń, mogą dzięki nim pozytywnie wpływać na efektywność nauki języka obcego. Dodatkowo nauczyciel świadomy różnic indywidualnych w grupie swoich uczniów może zarówno wspierać tych, którzy wsparcia potrzebują, jak i rozwijać potencjał uczniów uzdolnionych.

\section{BIBLIOGRAFIA}

Ackerman P. L., Chamorro-Premuzic T., Furnham A. (2011), Trait complexes and academic achievement: old and new ways of examining personality in educational contexts. "The British Journal of Educational Psychology", nr 81, s. 27-40.

Brzeziński J. (1984), Elementy metodologii badań psychologicznych. Warszawa: PWN.

Chamot A. U., Harris V. (2019), Learning Strategy Instruction in the Language

Classroom: Issues and Implementation. Bristol: Multilingual Matters.

Dörnyei Z. (2005), The psychology of the language learner: Individual differences in second language acquisition. M ahwah, $\mathrm{NJ}$ : Lawrence Erlbaum. Dörnyei Z., Ryan S. (2015), The psychology of the language learner revisited. London: Routledge.

Ehrman M., Oxford R. (1990), Adult language learning styles and strategies in an intensive training setting. „The M odern Language Journal”, nr 74, s. 311-327.

Ehrman, M ., Oxford, R. (1995), Cognition Plus: Correlates of Language Learning Success. "M odern Language Journal”, nr 79, s. 67-89.

Grenfell M., M acaro E. (2007), Claims and Critiques, (w:) Cohen A.D., M acaro E. (red.), Language Learning Strategies. Thirty Years of Research and Practice. Oxford: Oxford University Press, s. 9-28.

Heaven P. C. L., Ciarrochi J. (2012), When IQ is not everything: Intelligence, personality, and academic performance at school. „Personality and Individual Differences", nr 54, s. 518-522. 
Komorowska H. (2005), Metodyka nauczania języków obcych. Warszawa: Fraszka Edukacyjna.

Liyanage I. (2004), An exploration of language learning strategies and learner variables of Sri Lankan learners of English as a second language with special reference to their personality types. Sri Lanka: Griffith University. Liyanage I., Bartlett B. (2013), Personality types and languages learning strategies: Chameleons changing colours. "System”, nr 41(3), s. 598-608.

Naimann N., Fröhlich M., Stern H. H., Todesco A. (1978), The Good Language Learner. Toronto: OISE.

Nation, I. S. P. (2001), Learning Vocabulary in Another Language, Cambridge: Cambridge University Press.

O' Connor M . C., Paunonen S. V. (2007), Big Five personality predictors of postsecondary academic performance. „Personality and Individual Differences", nr 43(5), s. 971-990.

O'M alley M., Chamot A. U. (1990), Learning Strategies in Second Language Acquisition. Cambridge: Cambridge University Press.

Oxford R., Nyikos M . (1989), Variables Affecting Choice of Language Learning Strategies by University Students. „M odern Language Journal”, nr 73, s. 291-300. Oxford R. (1990), Language Learning Strategies. What Every Teacher Should Know. Boston: Heinle \& Heinle.

Oxford R. (2017), Teaching and Researching, Language Learning Strategies. Self-Regulation in Context. New York, London: Routledge.

Pawlak M. (2019), Czym sq różnice indywidualne w nauce języka obcego i jak sobie z nimi radzić? "Języki Obce w Szkole", nr 2, s. 5-12.

Pawlak M., Oxford R. L. (2018), Conclusion: The future of research into language learning strategies. "Studies in Second Language Learning and Teaching", nr 8, s. 523-532.

Pervin L. A. (2002), Psychologia osobowości. Gdańsk: Gdańskie Wydawnictwo Psychologiczne.

Przybył J. (2017), Determinanty korzystania ze strategii uczenia się języka angielskiego przez studentów poznańskich uczelni. „Neofilolog”, nr 48/1, s. 89-103. Rubin J. (1975), What the "Good Language Learner" Can Teach Us. „TESOL Quarterly" nr 9(1), s. 41-51.

Rubin J. (1981), Study of Cognitive Processes in Second Language Learning. „Applied Linguistics", nr 11, s. 117-131.

Schmitt N. (1997), Vocabulary learning strategies, (w:) Schmitt N., McCarthy M. (red.), Vocabulary: Description, Acquisition and Pedagogy. Cambridge: Cambridge University Press, s. 199-227.

Seretny A. (2015), Słownictwo w dydaktyce języka. Świat słów na przykładzie języka polskiego jako obcego. Kraków: Księgarnia Akademicka. 
Sharp A. (2009), Personality and second language learning. „Asian Social Science", nr 4, s. 17-25.

Stern H. H. (1975), What Can We Learn from the Good Language Learner? „Canadian M odern Language Review", nr 31(4), s. 304- 318.

Targońska J. (2011), Słabo rozwinięta kompetencja leksykalna dorosłych przyczyny, skutki i możliwości jej poprawy. „Neofilolog”, nr 37, s. 55-71. Targońska J., Stork A. (2013), Vorschläge für ein neues M odell zur Beschreibung und Analyse lexikalischer Kompetenz. „Zeitschrift für Fremdsprachenforschung", nr 24, s. 71-108.

Targońska J. (2016), Die Wortschatzarbeit im Fremdsprachenunterricht muss umkehren! Welchen Neuanfang bzw. welche neue Wortschatzwende brauchen wir? (w:) Jarząbek A. D. (red.), Anfang. Didaktische Implikationen für ein neues Lernparadigma. Königshausen \& Neumann: Würzburg, s. 79-93. Tschirner E. (2010), Wortschatz, (w:) Fandrych C., Krumm H.-J. (red.), Deutsch als Fremdsprache: Ein internationales Handbuch. New York/Berlin: M outon de Gruyter, s. 236-245.

Viebrock B. (2010), Lernstrategien, (w:) Surkamp C. (red.), Metzler Lexikon Fremdsprachendidaktik. Ansätze - M ethoden - Grundbegriffe. Stuttgart-Weimar: J. B. M etzler Verlag, s. 222-223.

Wakamoto N. (2000), Language learning strategy and personality variables: Focusing on extroversion and introversion. "International Review of Applied Linguistics", nr 38, s. 71-81.

Wysocka E. (2003), Inwentarz (Kwestionariusz) osobowości, (w:) Pilch T. (red.), Wielka Encyklopedia Pedagogiczna XXI wieku. t. II. Warszawa: Wydawnictwo Akademickie „Żak”, s. 226-231.

Wysocka E. (2004), Osobowość, (w:) Pilch T. (red.), Wielka Encyklopedia Pedagogiczna XXI wieku. t. III. Warszawa: Wydawnictwo Akademickie „Żak", s. 938-959.

Zawadzki B., Strelau J., Szczepaniak P., śliwińska M. (1998), Inwentarz Osobowości NEO-FFI Paula T. Costy i Roberta R. McCrae. Adaptacja polska. Warszawa: Pracownia Testów Psychologicznych PTP.

Zimbardo P.G., Johnson R. L., M ccann V. (2010), Psychologia. Kluczowe koncepcje. T. 4. Warszawa: PWN 